\title{
Development of Entrepreneurship Intentions Among School Students in Malaysia
}

\author{
Afiah Binti Sheikh Ismail ${ }^{1}$, Nor Aishah Buang ${ }^{2}$ \\ ${ }^{1,2}$ Faculty of Education, National University of Malaysia
}

DOI: 10.23917/ijolae.v1i1.7289

Accepted: December $8^{\text {th }}, 2018$. Approved: January $3^{\text {rd }}, 2019$. Published: January $31^{\text {th }}, 2019$

\begin{abstract}
Entrepreneurial education in school has long been an effort by authorities in improving participation among school leavers in entrepreneurship. Still, there are clear obstacle in making this a reality. Thus this conceptual paper will discuss the obstacles and solutions towards of making entrepreneurial education a success. Obstacles that will be discussed are such as the lack of knowledge of entrepreneurship among teachers and the obsolete methods of teaching and learning currently practiced. Several solutions to the obstacles will be addressed are such as new pedagogical approaches such as games and simulations. Plus, solutions from the industry itself is put forward with activities such as engagement and attachment being highlighted. Therefore a model framework has been develop form the combination of elements from past theories and models which are Critical Experiential Incidence Model by Krueger (2007), Constructivism Theory by Vygotsky (1978) and Theory of Planned Behavior by Ajzen (1991).
\end{abstract}

Keywords: Entrepreneurial Education, Entrepreneurial Intention, Teacher's Knowledge, Pedagogy

Corresponding Author:

Afiah Binti Sheikh Ismail, Faculty Pendidikan National University of Malaysia,

Email:afiahabad83@gmail.com

\section{Introduction}

Individual participation in entrepreneurial activities has been proven to enhance the Malaysian economy and also has the ability in reducing unemployment rates (Mohd Hasril et al, 2017). The longtime practice of the Malaysian Ministry of Education in promoting entrepreneurial values has been present in subjects such as Life Skills, Commerce and Principles of Entrepreneurship. Even so it is realized that Commerce which was the main player for entrepreneurial education only represents $23 \%$ of its contents on entrepreneurship. Realizing this the ministry had to forward a reform in entrepreneurial education by introducing a new subject called Business and Entrepreneurship starting from 2017. The objectives of such changes are not only to transform Malaysia into an internationally competitive entrepreneurial nation but also in debunking the negative view of entrepreneurial education in schools as ineffective.

The foundations of the introduction of the new subject is in order to strengthen the 5-point entrepreneurial elements in Malaysian schools put forward in 2012 which includes 1) practicing entrepreneurial attitudes, 2) practicing the entrepreneurial mind set, 3) practicing basic trading methods, 4) product development through knowledge, technological and vocational skills and 5) practicing values and ethics involving entrepreneurship. Even though the planning put forward by the ministry seems solid, still there are major concerns in the readiness of teachers in teaching entrepreneurial subjects especially in teaching and learning process, pedagogy, knowledge, teacher's interest and prior experiences in entrepreneurship as 
proven by Shahrin and Norsila (201). Realizing the gap that exist between the planning and execution process of entrepreneurial education in Malaysia it is imperative that this issue should be discussed and tackled as time, human resource and financial funding has been invested in effort of realizing the potential of Malaysia as an entrepreneurship hotbed.

\section{Development of Entrepreneurial In- tentions}

Entrepreneurial Intentions in past studies such as Kautonen et al. (2015) has shown it as a strong predictor of entrepreneurial behavior. Further studies by De Paco et al. (2015) strengthen the importance of entrepreneurial intentions at it seen as catalyst for business development for individuals. Thus, in realizing the aspirations in increasing the entrepreneurial involvement among Malaysians the development of entrepreneurial intentions is essential and one way of doing this is through entrepreneurial education in schools. Even though entrepreneurial education has been present in the school systems for a long period of time still studies such as by Abu Sufian et al. (2016) shows a worrying trend as $86 \%$ school students with entrepreneurial education background in school are disinterested in entrepreneurship. Furthermore, these adverse effects of the ministry's efforts are further proven by a study (Zulfaka et al., 2017) shows most entrepreneurship programs in schools failed to reach its objectives. It is clear that there are clear problems in the development of entrepreneurial intentions in school students in Malaysia thus problems should be addressed, and solutions should be discussed in improving the state of entrepreneurial education in Malaysia in achieving its purpose.

3. Problems in The Development of Entrepreneurial Intention at School Level in Malaysia
The Lack of Knowldege of Teachers in the Entrepreneurial Field

Shahrin and Siti Hasmah (2008) revealed that there is a clear lack of knowledge in teachers teaching entrepreneurial subjects in Malaysian schools. Most of teachers who are involved in entrepreneurial subjects gained their knowledge only through formal education from tertiary institution that they have attended and most have no hands-on experience in handling a business in real life. This has caused content taught in classes are purely based on books and sometimes the information in these books are obsolete by the time it is taught due to the dynamic nature of the business and entrepreneurial world itself which revolves around new ideas and concepts. The divide between schools and industry is clear as there is a lack of networking between these two establishments. Some have argued that the education system has drifted far from the basis it has being built upon which is the National Education Philosophy that focused on the holistic development of students in Malaysia based on the five areas of physical, emotional, spiritual, intellectual and social that should be mastered by all students in Malaysian schools. The shift of focusing solely on the intellectual side of education by the ever-growing emphasis on examination has made subjects such as entrepreneurial subjects are purely mastered for examination purposes that have killed its function in developing entrepreneurial intentions (Rosmani and Siti Aishah, 2016). Zulfaka et al.,(2014) further supports these phenomena by stating that most teachers teaching entrepreneurial subjects have very low product commercialization skills as most find it as unessential. Focus is more towards completing the syllabus and preparing students for examination as it is deemed as of higher importance. Furthermore, teachers have complained that the burdens of syllabus and examination gives very limited time for them to delve into encouraging students to 
develop entrepreneurial ideas. Thus, the gap between the realities of the entrepreneurial world and what is taught in schools is further widened by practices and pressures faced by teachers who teaches it.

\section{Inadequacy of Effective Methods in Deli- very of Entrepreneurial Subjects}

In achieving the objectives of entrepreneurial education past study (Jewell and Mankin, 2009) has shown that the effectiveness of teacher's delivery of lessons as a major factor in developing student's interest in entrepreneurship. Currently in Malaysian schools entrepreneurial subjects are mostly delivered to students in the conventional way which focuses more on theoretical and conceptual understanding with a clear lack of practical exposure to students (Ahmad Raflis et al., 2014). Mohamad Izzuan and Mohd Khata (2017) further argued that the conventional method of delivery has left little inspiration for students in furthering any aspirations in entrepreneurship as there are no basis of technical know-how or real life exposure in enhancing further enhancing understanding in entrepreneurship.

There have been previous efforts in improving entrepreneurial education such as the introduction of the Protune (Projek Tunas Niaga) project which is not part of the main curriculum but instead done as an extracurricular activity has been found to be ineffective and unappealing (Suraiya et al., 2018). The ineffectiveness of this effort is mostly attributed to the lack of understanding of the current Gen $\mathrm{Z}$ which have problems in situational awareness and the lack of the ability to give and follow orders in a normal situation. Realizing this there is a need in revising the pedagogical methods that are mostly conventional towards a method that is more concerned on the development of creative and innovative way of thinking which is deemed essential in todays world of entrepreneurship.
4. Suggestions on Solutions in Developing Entrepreneurial Intention at School Level in Malaysia

Involvement of Teachers in Industrial Linkages and Attachments

The quality of education reflects the quality of teachers who are responsible for its implementation and the achievements of its aspirations. These responsibilities are the backbone of the development of the future of the workforce of the nation such as Malaysia. Suraiya et al. (2018) stated that teachers are one of the main factors of entrepreneurial competency among students. Ruskovaara et al. (2015) highlighted that teachers involved in entrepreneurial education are needed to often update their knowledge on entrepreneurship especially on the current trends that are happening in the business world.

Therefore, by utilizing the current available channels in the teaching service in Malaysia that is practicing a compulsory training scheme which involves a series of training that is run throughout the year can be customized following the needs of the teachers teaching entrepreneurial subjects. Training which use to be more generic and theoretical should be tailored made and hands-on in meeting the demands of entrepreneurship. The trainings suggested are more towards engaging the industry which are directly involved in entrepreneurship. Training schemes which involves teaching being attached themselves to the industry should be introduce to enhance the knowhow of the teachers by gaining hands-on and real life experience of what they are teaching (Ruskovaara, 2015). Henceforth the engagement will create a valuable experience towards teachers which as been described in the Critical Experiential Incident Model by Krueger (2007) which focuses on how experience as a main driver towards change of behavior in a person or teacher in this case. 
Improvements in Pedagogical Practices in Entrepreneurial Education

Furthering the discussions of the challenges of educating the current Generation $Z$ is evident as Rothman (2016) explained that Generation $\mathrm{Z}$ is more responsive towards inputs based on visuals and practical application such as collaborative projects and interactive games which create challenges differing from the conventional lecture and discussion method that they find as unattractive. Furthermore, Thomas and Srinavisan (2016) stated that Generation $\mathrm{Z}$ appreciates things that are tangible and can be tested which further strengthen the reasoning of a shift in pedagogy towards a more hands-on approach of learning and teaching that is delivered through the wisdom of the teacher that was built form prior experience in entrepreneurship training in the industry.

The pedagogical approach of experiential learning is aligned with the Theory of Constructivism by Vygotsky (1978) which human learn from the experience they have learned and gaining new knowledge by experiencing it. This is achievable as students should be allowed to experience themselves the realities of entrepreneurship. As there is a great fit between Generation Z's learning preferences and the attributes of constructivism therefore it is only right that the appro- ach of teaching must be transformed in meeting the needs of students and attaining the real objectives of entrepreneurial education that is to induce entrepreneurial intention.

\section{Model Framework}

The model suggested for the future research will involve three variables which involves the input which is represented by Teacher's Industrial Attachment derived from Krueger (2007) Critical Experiential Incident Model where the experience attained from engagement and attachment that the teacher itself had experienced would change the teacher's perspective of entrepreneurship. Next, the input is predicted to effect the process which is represented by the Teacher's Pedagogical Practices which is derived from Vygotsky (1978) Theory of Constructivism where teacher's will build their pedagogical practices more towards a hands on and real life practices that is gained and trained during their industrial attachement. Finally, the output would be the Student's Entrepreneurial Intentions which will adapt the Theory of Planned Behavior by Ajzen (1991) which will see the effects of pedagogical approaches towards the entrepreneurial intentions of students.

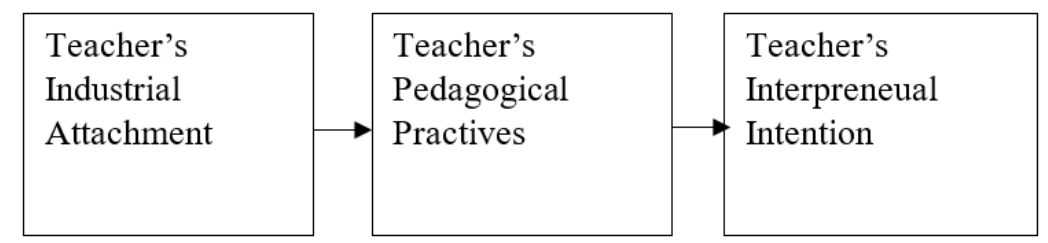

Figure 1. Research Model Framework

\section{Conclusion}

The current situation of entrepreneurial education in Malaysia indicates that there is a vital need for transformation or change on the way it is approached. Mere planning without proper implementation has been proven the root of the fallback of achieving the objectives of entrepreneurial education. In meeting the demands of the current gene- ration it is essential that the Ministry of Education of Malaysia should look into training teachers through industrial attachment which in turn will be of a real added value to the experience and knowledge of the teacher.

The experience gained itself would change the approach of the teacher itself in delivering to students information in a more 
creative and effective manner. Through all these effort it is truly hoped that it will create a higher percentage of students with entrepreneurial intentions.

\section{References}

Abu Sufian Abu Bakar, Abdul Rahim Anuar, Ahmad Zubir Ibrahim, Mohd Najib Mansor, Badariah Haji Din , Kalsom Kayat, Shazida Jan Mohd Khan, Nur Syamilah Md Noor, Wan Nurmahfuzah Jannah Wan Mansor \& Mariana Usman. 2016. "Micro Entrepreneur Profile in Malaysia" Konvensyen Pengurusan Potensi Belia ke Arah Pembinaan Negara Bangsa. hlm. 46-54.

Ahmad Raflis Che Omar, Abdullah Sanusi Othman, Suraiya Ishak, Jumat Abd Moen, Mohd Rizal Palil, Mohamad Abdul Hamid, Mohd Fauzu Mohd Jani. 2007. "Nurturing Malaysia's future entrepreneurs: Determinants of financial learning effectiveness in public institution of higher learning." Geografia-Malaysian Jounal of Society and Space, 10 (2).

Ajzen, I. 1991. " The theory of planned behavior. Organizational behavior and human decision processes. 50(2), 179211.

Do Paço, A., Ferreira, J. M., Raposo, M., Rodrigues, R. G., \& Dinis, A. 2015. Entrepreneurial intentions: is education enough?. International Entrepreneurship and Management Journal, 11(1), 57-75.

Jewell, J., \& Mankin, J. 2009. Standardizing financial statement analysis across the business curriculum: An interdisciplinary approach. In Allied Academies International Conference. Academy of Educational Leadership. Proceedings (Vol. 14, No. 2, p. 15). Jordan Whitney Enterprises, Inc.

Kautonen, T., van Gelderen, M., \& Fink, M. 2015. Robustness of the theory of planned behavior in predicting entrepreneurial intentions and actions. Entrepreneurship Theory and Practice, 39(3), 655674.

Krueger, N. (2007). "What lies beneath? The experiential essence of entrepreneurial
thinking'.Entrepreneurship Theory and Practice. 18(3), 91-104.

Mohamad Izzuan Mohd Ishar, Mohd Khata Jabor. 2017. Integration of Entrepreneurship Theories Towards Entrepreneurship Development among Students in Malaysia. Malaysian Journal of Social Sciences and Humanities (MJSSH), 2(1), 11-20.

Mohd Hasril Amiruddin, Siti Norain Jafaar, Noorazman Abd Samad. 2017 Level of Knowledge, Skill and Ability of Trainees in Electrical Wiring in Technical Entrepreneur Development" Sains Humanika 9: 1-5 : 109-117.

Rosmani Ali, Nor Aishah Buang. 2016 "Entrepreneurial Attribute and Teachers Readyness Facing Challenges in Change in Education. Jurnal Penyelidikan Ilmu Pendidikan. 1:76

Rothman, D. 2016. A Tsunami of learners called Generation Z. URL: http://www. mdle.

net/JoumaFA_Tsunami_of_Learners_Ca lled_Generation_Z.pdf.

Ruskovaara, E., Pihkala, T., Seikkula-Leino, J., \& Järvinen, M. R. 2015. Broadening the resource base for entrepreneurship education through teachers' networking activities. Teaching and Teacher Education, 47, 62-70.

Shahrin Hashim \& Siti Hasmah Binti Mohammad.2008. " Obstacles in Nurturing Entrepreneurial Attributes in Teaching and Learning in Schools from a Teacher's Perspective.

Suraiya Ishak , Ahmad Raflis Che Omar, Fahruddin Mustafa Al Bakri, Lokhman Hakim Osman. 2018. Learning practices and effect on the knowledge and skills development among $\mathrm{Z}$ generation. Geografia-Malaysian Journal of Society and Space, 14(1).

Shahrin Bin Hashim \& Norsila Binti Abdul Rahman 2017. "Tendencies of PKPG Teachers towards Entrepreneurial Sector" Fakulti Pendidikan, Universiti Teknologi Malaysia.

Thomas, Y., \& Srinivasan R. 2016. Emerging shifts in learning paradigms- From 
Millenials to the digital natives. International Journal of Applied Engineering Research, 11 (5), 361-3618.

Vygotsky, L. 1978. Interaction between learning and development. Readings on the development of children, 23(3): 34-41.
Zulfaka Ishak, Nor Aishah Buang, Lilia Halim. 2017. Attributes and Level of Thinking in Entrepreneurship: Readiness for Intregration of Entrepreneurial Mindset into Teaching Process in MRSM. JuPiDi: Jurnal Kepimpinan Pendidikan, 1(1), 53-64. 